\title{
Integrative Effects of Vine Water Relations and Grape Ripeness Level of Vitis vinifera L. cv. Shiraz/Richter 99. II. Grape Composi- tion and Wine Quality
}

J.J. Hunter ${ }^{1,2}$, C.G. Volschenk ${ }^{1}$, V. Novello ${ }^{3}$, A. Pisciotta ${ }^{4}$, M. Booyse ${ }^{5}$, G.W. Fouché ${ }^{1}$

(1) ARC Infruitec-Nietvoorbij ${ }^{1}$, Private Bag X5026, 7599 Stellenbosch, South Africa

(2) Stellenbosch University, Department of Viticulture and Enology, Private Bag XI, 7602 Matieland, Stellenbosch, South Africa

(3) University of Turin, Department of Agriculture, Forest and Food Sciences, via L. da Vinci 44, I-10095 Grugliasco, Italy

(4) University of Palermo, Department of Agriculture and Forestry Sciences, viale delle Scienze 11, 90128 Palermo, Italy

(5) ARC Biometry, Private Bag X5026, 7599 Stellenbosch, South Africa

Submitted publication: April 2014

Accepted for publication: July 2014

Key words: Grapevine, irrigation, water relations, canopy, grape ripeness, berry composition, wine quality, wine style

Regulation of grapevine water status is a common practice to manipulate grape composition and wine quality. In this investigation the effect of plant water status (two field water capacity-based irrigation levels, $\mathbf{7 5 \%}$ and $\mathbf{1 0 0 \%}$, applied at single and combined vine developmental stages) and ripeness level (harvesting at different soluble solid levels) on grape composition and wine quality of Vitis vinifera L. cv. Shiraz/ Richter 99 was determined. Integrative effects of vine water relations and grape ripeness level, specifically in a Mediterranean high winter rainfall area, have not yet been investigated systematically. Source:sink mechanisms and dynamics and compositional and physical changes during both green berry and ripening periods (and in response to environment changes), seemed critical for the final grape composition and wine quality/style. Despite relatively favourable conditions of the experiment terroir, additional water was still required to obtain best grape and wine quality. Skin colour and total phenolic contents were stimulated in particular by $75 \%$ (field water capacity) pea size (PS) irrigation, post-véraison (PV) irrigation and $75 \%$ pea size+post-véraison irrigation, until the last harvest stage. Treatments that included post-véraison irrigation were not negative in terms of ripening parameters. Increasing total soluble solids with ripening were not followed in parallel by anthocyanin potential. Anthocyanin extractability increased with ripening. A late, overripe harvest may result in wines that are slightly better coloured, but highly alcoholic and tannic. Furthermore, at high ripeness level, differences between treatments largely diminished. Over-ripeness of grapes may have tempering and even negative effects on expected outcomes of seasonal cultivation efforts to produce unique wines. This would not favour economic viability. Although non-irrigated wines failed to result in exceptional wine quality at any harvest stage, a better result in overall quality was obtained in comparison to irrigation treatments applied at all stages. Berry and wine composition results corresponded with findings on wine sensorial quality. The $75 \% \mathrm{PS}, \mathrm{PV}$ irrigation, and $\mathbf{7 5} \% \mathrm{PS}+\mathrm{PV}$ irrigation consistently resulted in good quality wines. At the first harvest stage, $75 \% \mathrm{PV}, \mathbf{1 0 0} \% \mathrm{PV}, \mathbf{7 5} \%$ $\mathrm{PS}+\mathrm{V}$ and $\mathbf{7 5} \% \mathrm{PS}+\mathrm{PV}$ irrigations gave most prominent wines; at the second harvest stage, vines irrigated $75 \%$ at $\mathrm{PS}, \mathbf{7 5} \%$ at $\mathrm{PS}+\mathrm{PV}$ and $75 \%$ at $\mathrm{PV}$ delivered most prominent wines; and at the third harvest stage, $75 \%$ PV, $100 \% \mathrm{PV}, \mathbf{7 5} \%$ PS and $75 \% \mathrm{PS}+\mathrm{PV}$ resulted in most prominent wines. These treatments represented different wine styles at each harvest stage. Restricted PS irrigation and PV irrigation, as single or combined treatments, featured prominently in favouring grape and wine composition and wine sensorial quality. Physical and compositional changes in ripening berries and the impact on wine quality and style were further clarified. New perspectives on managing time of harvesting with varying vine water status are given. Recommendations on vine water status management strategies required to obtain different grape composition and wine style are made.

\footnotetext{
${ }^{1}$ The Fruit, Vine and Wine Institute of the Agricultural Research Council 


\section{INTRODUCTION}

Under the influence of environmental conditions, the physiological activity and prioritising of leaves, roots and berries within the whole plant at different growth stages during the season have a steering effect on yield and grape composition to satisfy the requirements for quality wine or other end products (Hunter, 2000; Hunter \& Ruffner, 2001; Hunter et al., 2004; Hunter et al., 2010; Hunter \& Bonnardot, 2011; Hunter et al., 2011).

Manipulation by means of water deficit (and canopy management) during the pre-véraison period primarily regulates berry size, but also the eventual berry composition at ripeness, whereas manipulation during the post-véraison period mainly has an impact on grape composition (Ojeda et al., 2002). The physicochemical changes in both sources and sinks brought about by water relations affect the length of the grape-ripening period (and harvesting window), the level of ripeness and grape composition that may be achieved, and therefore the level of wine quality and potential for different styles of wine that may be obtained within a given terroir (Ojeda et al., 2002; Hunter et al., 2004; Deloire et al., 2005; Hunter \& Deloire, 2005, 2006; Myburgh, 2006; Nadal \& Hunter, 2007). In order to fully quantify the importance of vine water relations in grape composition and the suitability of the latter for a specific wine objective, changes should be monitored over an extended ripening period that includes low, moderate and high ripeness levels, to capture enhanced or delayed ripening induced by treatments.

Flavonoid (anthocyanins, flavan-3-ol condensed tannins, flavonols) and non-flavonoid (phenolic acids, stilbenes) phenolic compounds and derivatives play a prominent role in the colour, flavour, taste (astringency, bitterness, body), antioxidant, and free radical scavenging properties of red wines and generally receive much attention in studies focused on grape and wine quality (Gawel, 1998; RibéreauGayon et al., 2000; Esteban et al., 2001; Cliff et al., 2002; De Beer et al., 2002; Ojeda et al., 2002; Cheynier et al., 2006; Squadrito et al., 2010). Glycosidic bonding increases their solubility, transport and storage ability in primarily the grape berry dermal vacuoles (De, 2000). Macro-, meso- and micro-environmental conditions, as well as viticultural and oenological practices, would all affect these compounds either directly or indirectly via chemical and/or physical changes (Carbonneau et al., 2007; Iland et al., 2011). Together with, inter alia, soluble solids and titratable acidity (Hunter et al., 1991; Cliff et al., 2002; De Souza et al., 2005), the phenolic compounds therefore largely define the final wine quality.

In general, the outcomes of studies on the impact of grapevine water relations are difficult to compare because of a lack of information on various factors, ranging from environmental conditions (soil characteristics and climate) and genotypes (scion and rootstock) to the physiological status of the vine and the water deficit experienced by the vine, at different phenological/developmental stages. The focus of this study was on quantifying changes in grape composition and wine quality/style during the berry-ripening period under different vine water status levels, introduced by means of irrigation at different stages and levels (volumes) during the growth season as single or multiple applications.
This is an extension of an accompanying study that focused on physiological changes and the vegetative and reproductive growth balances in relation to vine water status and level of grape ripeness (Hunter et al., 2014).

\section{MATERIALS AND METHODS \\ Vineyard}

A seven-year-old Vitis vinifera L. cv. Shiraz (clone SH1A) vineyard, grafted onto Richter 99 (Vitis berlandieri $\mathrm{x}$ Vitis rupestris) (clone RY2A), was used. The vineyard was located on the Experiment Farm of the ARC Infruitec-Nietvoorbij in Stellenbosch, Western Cape, South Africa. The area is under the influence of a Mediterranean climate with winter rainfall, as discussed by Hunter and Bonnardot (2011). The VSP-trained, spur-pruned vineyard and practices that were applied are described in Hunter et al. (2014).

\section{Treatments and layout}

Fifteen treatments, comprising single and combined microsprinkler irrigations which differed in volume of water supplied and stage/s of application, were used as indicated in Table 1. Details of treatments and replications are given by Hunter et al. (2014). Measurements were done at berry set (BS), pea size berry (PS), véraison (V), postvéraison (PV) and three ripeness levels, using soluble solid contents as indicator of ripeness level, i.e. $23^{\circ} \mathrm{B}, 25^{\circ} \mathrm{B}$ and $27^{\circ} \mathrm{B}$ (approximately 14 days between ripeness levels, corresponding to the beginning, middle and end of March). Although the treatments were applied in summer for four years continuously, the mean values of the last two years of the experiment (2006/2007 and 2007/2008) are presented.

\section{Measurements and analyses}

Soil conditions and determinations, vegetative and reproductive growth, and physiological measurements and analyses are described in Hunter et al. (2014).

Soluble solids, titratable acidity and the $\mathrm{pH}$ of the grape must were determined by standard methods after crushing of the grapes for winemaking. Whole berries were analysed for total anthocyanins (potential and extractable), total tannins, total seed tannins and total phenolic index (Ribéreau-Gayon et al., 2000). Berries were also analysed for flavan-3-ol monomers and oligomers by the DMAC method according to Vivas et al. (1994) and for proanthocyanins according to Ojeda et al. (2002). Berry skin total anthocyanins $\left(\mathrm{A}_{520}\right)$ and total phenolics $\left(\mathrm{A}_{280}\right)$ were determined according to Hunter et al. (1991).

Grapes of all harvests were cooled to the same temperature $\left(20^{\circ} \mathrm{C}\right)$ before processing for winemaking. The grapes were destemmed and crushed, and the pomace was inoculated with commercial yeast (VIN 13 at a concentration of $30 \mathrm{~g} / \mathrm{hl}$ ). Alcoholic fermentation took place at a controlled temperature of $24^{\circ} \mathrm{C}$ (di-ammonium phosphate and $\mathrm{SO}_{2}$ were added to all fermentations at concentrations of $50 \mathrm{~g} / \mathrm{hl}$ and $50 \mathrm{mg} / \mathrm{L}$, respectively). The skin cap was pushed through three times per day to aid skin extraction. Fermentation on the skins averaged five days, after which the pomace was pressed and the wines stabilised and bottled.

Total phenolics and total anthocyanins of the bottled wines were determined spectrophotometrically at $\mathrm{A}_{280}$ and 
TABLE 1

Irrigation treatments applied to the Shiraz/Richter 99 vineyard.

\begin{tabular}{lcccc}
\hline Irrigation Treatment & Berry set & Pea size & Véraison & Post-véraison \\
\hline 1. No irrigation (NI) & $\mathrm{O}$ & $\mathrm{O}$ & $\mathrm{O}$ & $\mathrm{O}$ \\
$2.75 \%$ All stages (75\% All stages) & $3 / 4 \mathrm{X}$ & $3 / 4 \mathrm{X}$ & $3 / 4 \mathrm{X}$ & $3 / 4 \mathrm{X}$ \\
$3.100 \%$ All stages (All stages) & $\mathrm{X}$ & $\mathrm{X}$ & $\mathrm{X}$ & $\mathrm{X}$ \\
$4.75 \%$ Pea size (75\% PS) & $\mathrm{O}$ & $3 / 4 \mathrm{X}$ & $\mathrm{O}$ & $\mathrm{O}$ \\
$5.100 \%$ Pea size (PS) & $\mathrm{O}$ & $\mathrm{X}$ & $\mathrm{O}$ & $\mathrm{O}$ \\
$6.75 \%$ Véraison $(75 \% \mathrm{~V})$ & $\mathrm{O}$ & $\mathrm{O}$ & $3 / 4 \mathrm{X}$ & $\mathrm{O}$ \\
$7.100 \%$ Véraison $(\mathrm{V})$ & $\mathrm{O}$ & $\mathrm{O}$ & $\mathrm{X}$ & $\mathrm{O}$ \\
$8.75 \%$ Post-véraison $(75 \% \mathrm{PV})$ & $\mathrm{O}$ & $\mathrm{O}$ & $\mathrm{O}$ & $3 / 4 \mathrm{X}$ \\
$9.100 \%$ Post-véraison $(\mathrm{PV})$ & $\mathrm{O}$ & $\mathrm{O}$ & $\mathrm{O}$ & $\mathrm{X}$ \\
$10.75 \%$ Pea size \& véraison $(75 \% \mathrm{PS}+\mathrm{V})$ & $\mathrm{O}$ & $3 / 4 \mathrm{X}$ & $3 / 4 \mathrm{X}$ & $\mathrm{O}$ \\
$11.100 \%$ Pea size \& véraison $(\mathrm{PS}+\mathrm{V})$ & $\mathrm{O}$ & $\mathrm{X}$ & $\mathrm{X}$ & $\mathrm{O}$ \\
$12.75 \%$ Pea size \& post-véraison $(75 \% \mathrm{PS}+\mathrm{PV})$ & $\mathrm{O}$ & $3 / 4 \mathrm{X}$ & $\mathrm{O}$ & $3 / 4 \mathrm{X}$ \\
$13.100 \%$ Pea size \& post-véraison $(\mathrm{PS}+\mathrm{PV})$ & $\mathrm{O}$ & $\mathrm{X}$ & $\mathrm{O}$ & $\mathrm{X}$ \\
$14.75 \%$ Véraison \& post-véraison $(75 \% \mathrm{~V}+\mathrm{PV})$ & $\mathrm{O}$ & $\mathrm{O}$ & $3 / 4 \mathrm{X}$ & $3 / 4 \mathrm{X}$ \\
$15.100 \%$ Véraison \& post-véraison $(\mathrm{V}+\mathrm{PV})$ & $\mathrm{O}$ & $\mathrm{O}$ & $\mathrm{X}$ & $\mathrm{X}$ \\
\hline
\end{tabular}

Véraison $=$ at least $75 \%$ colouring of grapes

Post-véraison $=$ three weeks after véraison

$\mathrm{O}=$ No irrigation, $3 / 4 \mathrm{X}=$ irrigation to $75 \%$ field water capacity, $\mathrm{X}=$ irrigation to $100 \%$ field water capacity

$\mathrm{A}_{520}$ after proper dilution. Wines were sensorially analysed by a trained panel of eight judges (winemakers) from the SA Wine Industry approximately four months after bottling. A non-structured $100 \mathrm{~mm}$ line-scale method was used to indicate the level of intensity of a specific sensorial parameter (Jackson, 2002).

\section{Statistical analyses}

The experimental design was a randomised block with two replications and thirty vines per replicate. Treatment design was a split-plot. The main plot was a factorial with treatments and stages as factors. According to Little and Hills (1978), a split-plot principle can be applied to experiments where successive observations are made on the whole units over time (years). Analysis of variance was performed using SAS version 9.2 (SAS, 2012). The Shapiro-Wilk test was performed to test for non-normality (Shapiro \& Wilk, 1965). Student's t-Least Significant Difference was calculated at the 5\% significance level to compare treatment means (Ott, 1998). Principal component analysis (PCA) with the correlation matrix option was performed using XLSTAT (Anonymous, 2012) to investigate the relationship between the treatments and the variables (chemical and sensory).

\section{RESULTS AND DISCUSSION}

\section{General environmental conditions}

Temperature and rainfall patterns at the experiment location and the water relations of the vines were described by Hunter et al. (2014) and showed that, irrespective of treatment, soil water content patterns were generally followed. An increasing water deficit seemed evident from BS stage until the PV stage. Although the soil water contents showed a decreasing trend from the first to the second harvest stage, the water status of the vines seemed to increase during this time, most likely as a result of rainfall just before the second harvest stage. The general impression was that the vines were not overly stressed. This is in line with a relatively high base soil water fraction, which was also evident from the soil water content of the non-irrigated treatment, particularly in the deepest soil layer and at the last harvest stage. The treatment effects on soil water content diminished progressively from the first to the third ripeness stage. The soil clearly had a high water-holding capacity and buffer capacity against favourable evapotranspiration conditions (see Hunter et al., 2014).

\section{Bunch behaviour}

In line with earlier findings (Hunter et al., 2004), the berries reached their highest mass approximately three weeks after V (PV stage) (Hunter et al., 2014), but high base soil water under the conditions of the study seemed to prevent classic water deficit berry size reduction effects after that (Williams \& Matthews, 1990; McCarthy, 1999; Ojeda et al., 2002; Roby \& Matthews, 2004; Myburgh, 2005). Although bunch mass and volume already started to decrease from PV, the rachis reached its highest mass only at the first harvest stage, after which it decreased (data not shown). Rachis and berry behaviour seemed not to be concerted during ripening, and the rachis rather displayed more typical vegetative tissue characteristics (Hunter et al., 2014).

\section{Grape composition}

A general trend of more water, less soluble solid concentration occurred (Table 2). At the last harvest stage, the non-irrigated vines did not seem to be able to reach similar soluble solid concentrations as the irrigated vines, but the values were at least as high as the high volume fully irrigated vines. The titratable acidity contents generally followed opposite trends 
TABLE 2

Effect of level and stage of irrigation on must and berry skin composition of Shiraz/Richter 99.

\begin{tabular}{|c|c|c|c|c|c|c|c|c|}
\hline Stage & $\begin{array}{c}\text { Irrigation } \\
\text { Treatment } \\
\text { (stage+level) }\end{array}$ & $\begin{array}{c}\text { Total } \\
\text { soluble } \\
\text { solids }\left({ }^{0} \mathrm{~B}\right) \\
\end{array}$ & $\begin{array}{l}\text { Titratable } \\
\text { acid }(\mathrm{g} / \mathrm{l})\end{array}$ & pH & $\begin{array}{l}{ }^{\circ} \mathrm{B}: \mathrm{TA} \\
\text { ratio }\end{array}$ & $\begin{array}{c}\text { Skin water } \\
(\%)\end{array}$ & $\begin{array}{c}\text { Anthocyanin } \\
\mathbf{A}_{520}\end{array}$ & $\begin{array}{c}\text { Phenolics } \\
\mathbf{A}_{280}\end{array}$ \\
\hline \multirow[t]{5}{*}{$\mathbf{V}$} & NI & 12.3 & 15.65 & 2.71 & 0.78 & 76.2 & 1.48 & 1.50 \\
\hline & 75All stages & 10.6 & 17.45 & 2.68 & 0.61 & 75.9 & 1.00 & 1.13 \\
\hline & 100All stages & 11.2 & 18.40 & 2.66 & 0.61 & 74.8 & 1.01 & 1.12 \\
\hline & 75PS & 11.2 & 16.00 & 2.72 & 0.70 & 75.2 & 1.17 & 1.26 \\
\hline & 100PS & 10.6 & 18.95 & 2.64 & 0.56 & 76.6 & 0.76 & 0.96 \\
\hline \multirow[t]{9}{*}{ PV } & NI & 19.6 & 6.60 & 3.38 & 2.97 & 71.6 & 2.55 & 2.47 \\
\hline & 75All stages & 18.7 & 6.35 & 3.44 & 2.94 & 73.9 & 1.89 & 1.96 \\
\hline & 100All stages & 18.0 & 6.90 & 3.39 & 2.61 & 73.7 & 1.81 & 1.87 \\
\hline & 75PS & 20.9 & 6.30 & 3.45 & 3.32 & 71.0 & 2.36 & 2.23 \\
\hline & 100PS & 18.3 & 6.55 & 3.42 & 2.80 & 72.4 & 1.97 & 1.99 \\
\hline & $75 \mathrm{~V}$ & 20.1 & 6.10 & 3.41 & 3.29 & 71.8 & 2.24 & 2.27 \\
\hline & $100 \mathrm{~V}$ & 19.0 & 6.25 & 3.39 & 3.03 & 72.6 & 2.13 & 2.15 \\
\hline & 75PS+V & 20.0 & 6.08 & 3.45 & 3.29 & 70.9 & 2.45 & 2.38 \\
\hline & 100PS+V & 18.3 & 6.68 & 3.43 & 2.74 & 72.1 & 2.04 & 2.03 \\
\hline \multirow[t]{15}{*}{ H1 } & NI & 21.6 & 4.43 & 4.12 & 4.88 & 70.3 & 2.29 & 2.24 \\
\hline & 75All stages & 21.3 & 4.53 & 4.24 & 4.69 & 70.5 & 1.75 & 1.80 \\
\hline & 100All stages & 21.0 & 4.73 & 4.13 & 4.44 & 71.0 & 1.86 & 1.90 \\
\hline & 75PS & 23.3 & 4.75 & 4.15 & 4.90 & 67.8 & 2.68 & 2.53 \\
\hline & 100PS & 21.8 & 4.71 & 4.10 & 4.63 & 70.1 & 2.35 & 2.32 \\
\hline & $75 \mathrm{~V}$ & 22.4 & 4.62 & 4.01 & 4.85 & 69.3 & 2.29 & 2.29 \\
\hline & $100 \mathrm{~V}$ & 21.7 & 4.34 & 3.84 & 4.99 & 70.0 & 2.36 & 2.35 \\
\hline & $75 \mathrm{PV}$ & 23.0 & 4.34 & 4.02 & 5.30 & 69.6 & 2.42 & 2.32 \\
\hline & $100 \mathrm{PV}$ & 22.5 & 4.32 & 4.37 & 5.21 & 68.2 & 2.61 & 2.57 \\
\hline & 75PS+V & 22.0 & 4.50 & 4.07 & 4.89 & 68.3 & 2.61 & 2.54 \\
\hline & $100 P S+V$ & 20.2 & 4.90 & 4.24 & 4.12 & 71.4 & 1.79 & 1.83 \\
\hline & 75PS+PV & 22.5 & 4.86 & 4.14 & 4.62 & 68.9 & 2.59 & 2.49 \\
\hline & 100PS+PV & 21.9 & 4.65 & 3.94 & 4.72 & 69.8 & 2.24 & 2.19 \\
\hline & $75 V+P V$ & 22.5 & 4.44 & 3.85 & 5.06 & 68.8 & 2.44 & 2.41 \\
\hline & $100 \mathrm{~V}+\mathrm{PV}$ & 20.5 & 4.30 & 4.04 & 4.75 & 70.9 & 2.03 & 2.13 \\
\hline \multirow[t]{15}{*}{$\mathbf{H} 2$} & NI & 25.1 & 4.18 & 3.83 & 6.01 & 65.9 & 2.27 & 2.24 \\
\hline & 75All stages & 24.6 & 4.08 & 3.92 & 6.03 & 67.9 & 1.76 & 1.83 \\
\hline & 100All stages & 24.1 & 4.60 & 3.83 & 5.23 & 66.5 & 2.05 & 2.06 \\
\hline & 75PS & 25.8 & 4.28 & 3.85 & 6.04 & 64.9 & 2.33 & 2.06 \\
\hline & 100PS & 25.5 & 4.35 & 3.92 & 5.86 & 66.0 & 2.16 & 1.87 \\
\hline & $75 \mathrm{~V}$ & 25.3 & 4.00 & 3.90 & 6.33 & 66.0 & 2.14 & 2.10 \\
\hline & $100 \mathrm{~V}$ & 24.5 & 4.28 & 3.92 & 5.73 & 67.6 & 2.01 & 2.05 \\
\hline & 75PV & 26.3 & 4.28 & 3.81 & 6.14 & 65.2 & 2.37 & 2.31 \\
\hline & $100 \mathrm{PV}$ & 26.6 & 4.13 & 3.85 & 6.45 & 66.2 & 2.34 & 2.29 \\
\hline & 75PS $+\mathrm{V}$ & 26.5 & 4.35 & 3.93 & 6.08 & 66.0 & 2.01 & 1.99 \\
\hline & $100 P S+V$ & 22.6 & 4.40 & 3.80 & 5.13 & 68.4 & 1.68 & 1.74 \\
\hline & 75PS+PV & 26.0 & 4.00 & 3.96 & 6.50 & 66.2 & 2.14 & 2.08 \\
\hline & $100 P S+P V$ & 25.6 & 4.30 & 3.87 & 5.94 & 66.1 & 2.09 & 2.05 \\
\hline & $75 \mathrm{~V}+\mathrm{PV}$ & 25.5 & 4.13 & 3.93 & 6.18 & 67.2 & 1.91 & 1.91 \\
\hline & $100 \mathrm{~V}+\mathrm{PV}$ & 24.3 & 4.38 & 3.78 & 5.55 & 67.1 & 2.05 & 2.06 \\
\hline
\end{tabular}


TABLE 2 (CONTINUED)

\begin{tabular}{|c|c|c|c|c|c|c|c|c|}
\hline Stage & $\begin{array}{c}\text { Irrigation } \\
\text { Treatment } \\
\text { (stage+level) }\end{array}$ & $\begin{array}{c}\text { Total } \\
\text { soluble } \\
\text { solids }\left({ }^{0} \mathrm{~B}\right)\end{array}$ & $\begin{array}{c}\text { Titratable } \\
\text { acid (g/l) }\end{array}$ & pH & $\begin{array}{l}{ }^{\circ} \mathbf{B}: \mathbf{T A} \\
\text { ratio }\end{array}$ & $\begin{array}{c}\text { Skin water } \\
(\%)\end{array}$ & $\begin{array}{c}\text { Anthocyanin } \\
\mathbf{A}_{520}\end{array}$ & $\begin{array}{c}\text { Phenolics } \\
\mathbf{A}_{280}\end{array}$ \\
\hline \multirow[t]{16}{*}{ H3 } & NI & 25.7 & 3.20 & 4.10 & 8.02 & 62.6 & 1.86 & 1.88 \\
\hline & 75All stages & 26.6 & 3.63 & 4.08 & 7.33 & 64.8 & 1.42 & 1.49 \\
\hline & 100All stages & 25.7 & 3.48 & 4.03 & 7.40 & 65.0 & 1.49 & 1.57 \\
\hline & 75PS & 28.6 & 3.50 & 4.02 & 8.18 & 61.4 & 1.98 & 2.02 \\
\hline & 100PS & 26.9 & 3.35 & 4.06 & 8.03 & 63.3 & 1.61 & 1.68 \\
\hline & $75 \mathrm{~V}$ & 28.2 & 3.08 & 4.08 & 9.18 & 62.1 & 1.78 & 1.85 \\
\hline & $100 \mathrm{~V}$ & 26.5 & 3.25 & 4.04 & 8.16 & 63.7 & 1.89 & 1.98 \\
\hline & 75PV & 28.0 & 3.28 & 4.03 & 8.54 & 62.9 & 1.97 & 1.97 \\
\hline & 100PV & 29.1 & 3.38 & 4.10 & 8.61 & 63.1 & 2.12 & 2.15 \\
\hline & $75 \mathrm{PS}+\mathrm{V}$ & 26.9 & 3.25 & 4.08 & 8.27 & 63.4 & 1.78 & 1.82 \\
\hline & $100 P S+V$ & 25.2 & 3.70 & 3.97 & 6.80 & 64.5 & 1.73 & 1.79 \\
\hline & 75PS+PV & 27.7 & 3.23 & 4.09 & 8.57 & 62.3 & 2.20 & 2.18 \\
\hline & 100PS+PV & 28.3 & 3.35 & 4.13 & 8.44 & 62.5 & 1.84 & 1.88 \\
\hline & $75 \mathrm{~V}+\mathrm{PV}$ & 28.4 & 3.08 & 4.14 & 9.23 & 62.2 & 1.88 & 1.94 \\
\hline & $100 V+P V$ & 26.2 & 3.45 & 4.00 & 7.59 & 64.3 & 1.82 & 1.86 \\
\hline & $L S D(p=0.05)$ & 1.5993 & 0.7049 & 0.1872 & 0.8256 & 1.864 & 0.3159 & 0.3217 \\
\hline
\end{tabular}

$\mathrm{PS}=$ Pea size; $\mathrm{V}=$ Véraison; $\mathrm{PV}=$ Post-véraison; $75=75 \%$ field water capacity irrigation; $100=100 \%$ field water capacity irrigation; $\mathrm{NI}=$ No irrigation; Trm. av. = Treatment average; $\mathrm{H} 1=$ Harvest $1 ; \mathrm{H} 2=$ Harvest 2; $\mathrm{H} 3=$ Harvest 3

and the $\mathrm{pH}$ values similar trends to those of the soluble solids. As referred to in Hunter et al. (2014), the vines seemed to display independence from soil water during ripening. This became more pronounced as ripening proceeded. The senescing canopy produced less and hoarded more sucrose and the berries lost more water than they could gain by water potential gradients. This also is evident from the skin water content (Table 2).

The ${ }^{\circ} \mathrm{B}$ :TA ratios [indicating quality standards for Shiraz (Hunter et al., 2004)] at the three harvest dates showed that ratios were generally higher with less irrigation volume (Table 2). The ratios were only inside the criteria for quality wine styles at the first and second harvest stages (Hunter et al., 2004). At the third harvest stage the ratios were outside the range for quality wine potential and the grapes were clearly overripe. A delayed ripening of vines irrigated at all stages was evident at the third harvest stage. Although the non-irrigated vines showed delayed soluble solid contents and low acidity at the last harvest stages, ${ }^{\circ} \mathrm{B}$ :TA ratios were not markedly lower.

Skin anthocyanin and phenolic contents indicated that the development of colour was already almost complete approximately three weeks after $\mathrm{V}$ at a soluble solid concentration of approximately 18 to $20^{\circ} \mathrm{B}$ (Table 2). This is in agreement with results found previously (Hunter et al., 2004; Nadal \& Hunter, 2007), and with detailed individual anthocyanin and tannin composition studies by Hilbert et al. (2003) and Fournand et al. (2006). Skin colour was generally highest at the first harvest stage, after which it decreased until the last harvest stage, which may suggest a change from free anthocyanins to derivatised anthocyanins (Fournand et al., 2006). At the latter stage, grapes were overripe. From Fig. 1 it is clear that the soluble solid concentration and the skin anthocyanin contents proceeded in opposite directions as ripening continued. This is similar to the results found by Hilbert et al. (2003) and Fournand et al. (2006), but in contrast to those reported by others (Keller \& Hrazdina, 1998; Esteban et al., 2002). The improvement in skin colour from $\mathrm{V}$ was accompanied by a loss in skin water content (Table 2). A steady loss of water from the skins occurred for all treatments from the PV stage, but least for the vines irrigated throughout the season at all stages. None of the treatments, however, were markedly successful in maintaining higher skin water contents. Skin colour, as well as total phenolic contents, was particularly stimulated by $75 \%$ PS irrigation, PV irrigation and $75 \%$ PS + PV irrigation until the last harvest stage. Contrary to general belief, treatments that included PV irrigation did not seem negative in terms of ripening parameters. According to Borsani et al. (2010), a period of water deficit close to $\mathrm{V}$ may prematurely induce anthocyanin biosynthesis gene expression (of chalcone synthase, flavonoid-3-hydroxylase, dihydroflavonol reductase and UDP-glucoflavonoid-3-oglucosyl transferase). With the exception of UFGT, this also occurred with a deficit period close to harvest. In this study, a mild deficit therefore stimulated flavonoid accumulation.

Although the expression of anthocyanin potential on a whole berry basis was at least two times higher at $\mathrm{pH} 1.0$ (total available anthocyanin) than at $\mathrm{pH} 3.2$ (average wine medium), the trends were similar and showed a general increase until the last harvest stage (Table 3). This is in accordance with results found by Guidoni \& Argamante (2003). Although related, the anthocyanin potential seemed not to have increased in full tandem with the total soluble 


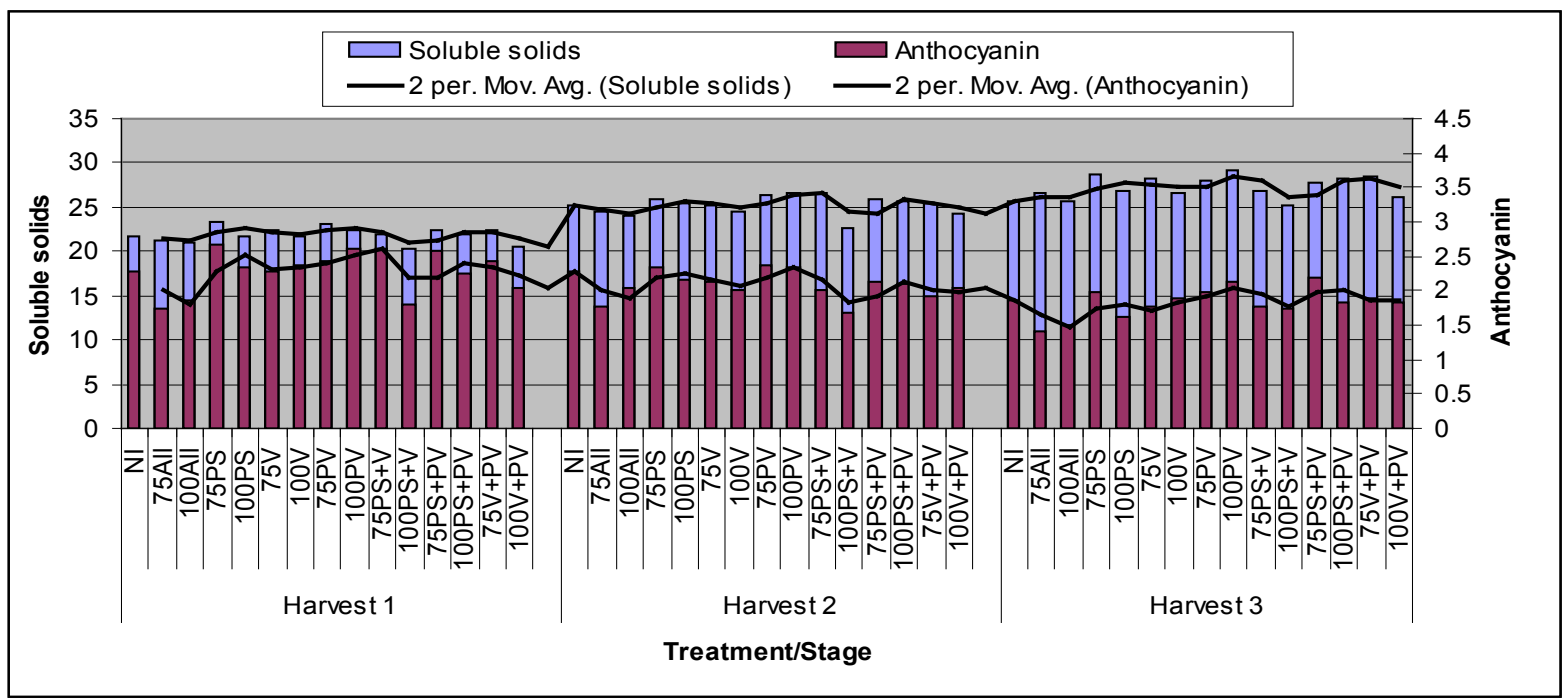

FIGURE 1

Effect of level and stage of irrigation on the relationship between skin anthocyanin $\left(\mathrm{A}_{520}\right)$ and must soluble solids $\left({ }^{\circ} \mathrm{B}\right)$ of Shiraz/ Richter 99.

solids with further ripening (Figs $2 \& 3$ ). As expected, the anthocyanin extractability generally decreased with ripening (lower values indicate higher extractability - RibéreauGayon et al., 2000); this was more pronounced from the first to the second harvest. Berries of the non-irrigated (NI) vines and most of the treatments that included PV irrigation showed increased extractability with ripening. Even if the skin anthocyanin content actually decreased during this time (Fig. 1), extraction may still have increased because of the simultaneous effect of the reduction in berry volume (and concomitant increase in skin:pulp ratio) during this time (Hunter et al., 2014) as well as the softening of the berries as ripening proceeded. A loss in cellular integrity during the softening and shrinking process (a change in cell wall polysaccharides, possibly brought about by cell wall enzymes such as, amongst others, endo- and exo-hydrolases and endo-polygalacturonase - Dreier et al., 1998; Nunan et al., 1998) may have occurred. This is also in line with the reduction in sucrose contents and the possible involvement of the sucrose-hydrolysing invertase enzymes in the skin during this time (Ruffner et al., 1990; Zhang et al., 2006; Hunter et al., 2014). On a physical level, the reduction in skin water contents as ripening proceeded may have further concentrated the extraction. A predetermined relationship between extractability and optimal technological readiness should not be accepted automatically (González-Nevez et al., 2002).

Similar trends to what were found with skin colour and phenolic contents were also evident in the wine colour and phenolic profiles (Table 4). However, the individual anthocyanin profiles in the grape skins may have differed from those in the wines (Squadrito et al., 2010). Although the usefulness of the anthocyanin extractability index is questioned by some (Bautista-Ortín et al., 2006), it seems that it may indeed be another indicator of harvest and wine style differences. In fact, it could significantly affect decisions during the fermentation process in terms of duration, frequency and intensity of pump-over, temperature control and enzyme/tannin addition (Romero-Cascales et al., 2005). It may be expected that a late harvest (as represented here by the third harvest stage) would result in wines that are slightly better coloured, but highly alcoholic and tannic, despite the ostensible complex formation (polymerisation) of the tannin monomers. The interplay between an increasing alcohol level with a higher ripeness level and phenolic extraction is a significant factor in the tailoring of the phenolic composition and quality of the final wine (González-Neves et al., 2002; Guidoni \& Hunter, 2012).

Trends regarding the treatment effects on whole berries were similar to those found in the skins (Table 3). The total tannin contents, seed tannins and total phenolics also increased with the development of the berry and as ripening progressed. In contrast, the total flavan-3-ol monomer levels (tannin monomers expressed as catechin) decreased until PV and then remained reasonably stable until the last harvest stage. If this can be taken as an indication that the degree of polymerisation increased during berry development until it reached a stable phase, the results may be in accordance with those found by Hanlin \& Downey (2009), obtained with more sophisticated and elaborate methods on the condensed tannin composition. A reduction in catechin content with increasing maturity was observed for Merlot and Cabernet Sauvignon skin tissue by De Freitas et al. (2000).

The wines made from NI vines increased in colour with ripening, but failed to result in exceptional colour at any stage. In a study on pre- and post-véraison water deficit, Sipiora \& Granda (1998) also found that, despite a realisation of a smaller berry size in the pre-véraison deficit treatment, anthocyanin and total phenols were not increased in the wines. Skin contact time apparently exerted a more pronounced effect than water deficit on the quantities of these compounds in the wines. In this study, it is clear that water was needed under the conditions of the specific terroir (despite the rainfall that occurred during ripening, as shown in Hunter et al., 2014), but that $75 \%$ or $100 \%$ irrigation (to field water capacity) at all stages was excessive. As found 
TABLE 3

Effect of level and stage of irrigation on whole berry composition of Shiraz/Richter 99.

\begin{tabular}{|c|c|c|c|c|c|c|c|c|c|c|}
\hline Stage & $\begin{array}{c}\text { Irrigation } \\
\text { Treatment } \\
\text { (stage+level) }\end{array}$ & $\begin{array}{c}\text { Antho pot } \\
\text { (mg/l) } \\
\text { pH 1.0 }\end{array}$ & $\begin{array}{c}\text { Antho pot } \\
\text { (mg/l) } \\
\text { pH } 3.2 \\
\end{array}$ & $\begin{array}{l}\mathrm{AE} \\
(\%) \\
\end{array}$ & $\begin{array}{c}\text { Tannin } \\
(\mathrm{g} / \mathrm{l}) \\
\text { pH 1.0 }\end{array}$ & $\begin{array}{c}\text { MP } \\
(\%) \\
\text { pH 3.2 } \\
\end{array}$ & $\begin{array}{c}\text { I } 280 \\
\text { pH } 1.0\end{array}$ & $\begin{array}{c}\text { I } 280 \\
\text { pH } 3.2\end{array}$ & $\begin{array}{c}\text { DMAC } \\
\text { (mg Cat Eq/ } \\
\text { gFM) } \\
\text { pH } 1.0\end{array}$ & $\begin{array}{c}\text { DMAC } \\
\text { (mg Cat } \\
\text { Eq/gFM) } \\
\text { pH } 3.2 \\
\end{array}$ \\
\hline \multirow[t]{3}{*}{ PS } & NI & 5.7 & 6.1 & -7.7 & 1.52 & 23.4 & 33.8 & 30.5 & 0.46 & 0.43 \\
\hline & 75All stages & 3.9 & 6.1 & -55.6 & 1.37 & 20.1 & 33.0 & 28.2 & 0.47 & 0.37 \\
\hline & 100All stages & 3.1 & 4.4 & -42.9 & 1.48 & 25.6 & 35.1 & 35.1 & 0.48 & 0.44 \\
\hline \multirow[t]{5}{*}{$\mathbf{V}$} & NI & 297.9 & 116.8 & 60.8 & 2.39 & 17.4 & 31.6 & 16.4 & 0.21 & 0.13 \\
\hline & 75All stages & 219.2 & 88.8 & 59.5 & 2.38 & 16.9 & 30.8 & 17.5 & 0.26 & 0.18 \\
\hline & 100All stages & 185.5 & 80.9 & 56.4 & 2.02 & 15.7 & 28.4 & 15.8 & 0.23 & 0.16 \\
\hline & 75PS & 223.6 & 108.9 & 51.3 & 2.28 & 16.5 & 29.7 & 16.5 & 0.22 & 0.14 \\
\hline & 100PS & 184.6 & 82.3 & 55.5 & 1.43 & 21.1 & 29.5 & 18.6 & 0.30 & 0.20 \\
\hline \multirow[t]{9}{*}{ PV } & NI & 642.3 & 256.8 & 60.0 & 3.53 & 30.7 & 50.9 & 22.3 & 0.14 & 0.09 \\
\hline & 75All stages & 449.3 & 179.8 & 60.0 & 3.22 & 25.9 & 40.0 & 17.8 & 0.14 & 0.08 \\
\hline & 100All stages & 444.1 & 185.9 & 58.1 & 3.33 & 28.9 & 40.2 & 18.7 & 0.14 & 0.08 \\
\hline & 75PS & 715.3 & 296.2 & 58.6 & 3.80 & 32.6 & 55.7 & 24.2 & 0.15 & 0.08 \\
\hline & 100PS & 431.4 & 164.1 & 62.0 & 3.06 & 25.3 & 38.6 & 18.2 & 0.14 & 0.09 \\
\hline & $75 \mathrm{~V}$ & 567.4 & 246.8 & 56.5 & 3.35 & 27.9 & 46.6 & 21.5 & 0.13 & 0.08 \\
\hline & $100 \mathrm{~V}$ & 559.6 & 223.6 & 60.0 & 3.29 & 28.4 & 45.2 & 19.5 & 0.13 & 0.07 \\
\hline & 75PS+V & 621.3 & 244.6 & 60.6 & 3.43 & 30.6 & 49.6 & 22.0 & 0.13 & 0.08 \\
\hline & $100 P S+V$ & 496.1 & 200.8 & 59.5 & 3.29 & 23.8 & 42.2 & 19.6 & 0.14 & 0.08 \\
\hline \multirow[t]{15}{*}{ H1 } & NI & 515.4 & 207.4 & 59.8 & 3.76 & 37.4 & 46.1 & 21.8 & 0.11 & 0.07 \\
\hline & 75All stages & 461.6 & 201.7 & 56.3 & 3.72 & 36.1 & 43.4 & 21.3 & 0.11 & 0.07 \\
\hline & 100All stages & 495.7 & 213.9 & 56.8 & 3.80 & 38.8 & 45.1 & 22.8 & 0.12 & 0.09 \\
\hline & 75PS & 756.0 & 330.8 & 56.3 & 4.15 & 40.9 & 58.9 & 28.7 & 0.13 & 0.09 \\
\hline & 100PS & 568.3 & 231.4 & 59.3 & 3.76 & 36.2 & 48.6 & 22.4 & 0.11 & 0.08 \\
\hline & $75 \mathrm{~V}$ & 582.3 & 265.1 & 54.5 & 4.02 & 40.8 & 51.4 & 24.0 & 0.11 & 0.07 \\
\hline & $100 \mathrm{~V}$ & 546.0 & 258.1 & 52.7 & 3.71 & 36.3 & 48.8 & 24.8 & 0.10 & 0.07 \\
\hline & 75PV & 667.2 & 278.7 & 58.2 & 3.72 & 40.6 & 55.6 & 24.8 & 0.11 & 0.08 \\
\hline & 100PV & 614.7 & 265.1 & 56.9 & 3.93 & 38.4 & 52.3 & 25.3 & 0.11 & 0.08 \\
\hline & 75PS+V & 610.8 & 253.8 & 58.5 & 3.98 & 38.7 & 51.6 & 24.7 & 0.11 & 0.07 \\
\hline & $100 P S+V$ & 446.7 & 196.9 & 55.9 & 3.56 & 34.5 & 41.9 & 21.1 & 0.11 & 0.07 \\
\hline & 75PS+PV & 700.0 & 297.1 & 57.6 & 4.08 & 37.1 & 57.8 & 25.7 & 0.13 & 0.08 \\
\hline & $100 P S+P V$ & 564.4 & 234.5 & 58.5 & 3.61 & 34.9 & 47.1 & 22.0 & 0.11 & 0.07 \\
\hline & $75 \mathrm{~V}+\mathrm{PV}$ & 602.0 & 263.4 & 56.3 & 4.09 & 40.2 & 51.9 & 24.9 & 0.12 & 0.08 \\
\hline & $100 \mathrm{~V}+\mathrm{PV}$ & 449.3 & 204.3 & 54.5 & 3.75 & 37.1 & 43.4 & 21.7 & 0.11 & 0.08 \\
\hline \multirow[t]{15}{*}{ H2 } & NI & 613.4 & 268.2 & 56.3 & 4.31 & 47.0 & 51.3 & 25.7 & 0.13 & 0.09 \\
\hline & 75All stages & 469.9 & 224.0 & 52.3 & 4.51 & 50.2 & 45.1 & 24.8 & 0.11 & 0.09 \\
\hline & 100All stages & 514.1 & 212.6 & 58.6 & 4.47 & 47.5 & 47.9 & 23.3 & 0.13 & 0.08 \\
\hline & 75PS & 679.0 & 286.1 & 57.9 & 4.71 & 50.6 & 58.9 & 29.5 & 0.14 & 0.10 \\
\hline & 100PS & 628.3 & 299.3 & 52.4 & 4.60 & 49.6 & 55.1 & 30.6 & 0.13 & 0.10 \\
\hline & $75 \mathrm{~V}$ & 599.4 & 295.3 & 50.7 & 4.64 & 52.8 & 51.6 & 29.1 & 0.13 & 0.10 \\
\hline & $100 \mathrm{~V}$ & 531.6 & 233.6 & 56.0 & 4.40 & 50.3 & 48.1 & 26.1 & 0.12 & 0.08 \\
\hline & $75 \mathrm{PV}$ & 664.1 & 303.2 & 54.3 & 4.67 & 50.0 & 53.3 & 27.9 & 0.12 & 0.08 \\
\hline & $100 \mathrm{PV}$ & 645.3 & 298.4 & 53.8 & 4.87 & 49.5 & 55.3 & 29.3 & 0.14 & 0.10 \\
\hline & $75 P S+V$ & 591.1 & 271.3 & 54.1 & 4.64 & 51.9 & 52.6 & 27.9 & 0.11 & 0.08 \\
\hline & $100 \mathrm{PS}+\mathrm{V}$ & 436.2 & 209.1 & 52.1 & 3.86 & 46.1 & 43.0 & 24.3 & 0.12 & 0.10 \\
\hline & 75PS+PV & 714.0 & 312.8 & 56.2 & 4.60 & 51.3 & 59.1 & 30.0 & 0.13 & 0.10 \\
\hline & 100PS+PV & 574.9 & 279.1 & 51.4 & 4.69 & 49.9 & 52.6 & 27.5 & 0.13 & 0.09 \\
\hline & $75 V+P V$ & 602.9 & 278.7 & 53.8 & 4.76 & 53.0 & 52.5 & 27.8 & 0.12 & 0.09 \\
\hline & $100 \mathrm{~V}+\mathrm{PV}$ & 567.0 & 245.9 & 56.6 & 4.34 & 44.9 & 50.9 & 25.1 & 0.12 & 0.08 \\
\hline
\end{tabular}




\begin{tabular}{|c|c|c|c|c|c|c|c|c|c|c|}
\hline Stage & $\begin{array}{c}\text { Irrigation } \\
\text { Treatment } \\
\text { (stage+level) }\end{array}$ & $\begin{array}{c}\text { Antho pot } \\
\text { (mg/l) } \\
\text { pH 1.0 }\end{array}$ & $\begin{array}{c}\text { Antho pot } \\
\text { (mg/l) } \\
\text { pH 3.2 }\end{array}$ & $\begin{array}{l}\text { AE } \\
(\%)\end{array}$ & $\begin{array}{c}\text { Tannin } \\
(\mathrm{g} / \mathrm{l}) \\
\text { pH } 1.0\end{array}$ & $\begin{array}{c}\text { MP } \\
(\%) \\
\text { pH 3.2 }\end{array}$ & $\begin{array}{c}\text { I } 280 \\
\text { pH } 1.0\end{array}$ & $\begin{array}{c}\text { I } 280 \\
\text { pH } 3.2\end{array}$ & $\begin{array}{c}\text { DMAC } \\
\text { (mg Cat Eq/ } \\
\text { gFM) } \\
\text { pH } 1.0\end{array}$ & $\begin{array}{c}\text { DMAC } \\
\text { (mg Cat } \\
\text { Eq/gFM) } \\
\text { pH } 3.2\end{array}$ \\
\hline \multirow[t]{16}{*}{ H3 } & NI & 675.9 & 301.9 & 55.3 & 5.31 & 60.5 & 62.2 & 32.1 & 0.14 & 0.11 \\
\hline & 75All stages & 498.8 & 238.9 & 52.1 & 5.10 & 58.0 & 52.8 & 28.9 & 0.12 & 0.08 \\
\hline & 100All stages & 498.3 & 228.8 & 54.1 & 4.98 & 57.9 & 51.8 & 28.1 & 0.13 & 0.09 \\
\hline & 75PS & 704.4 & 335.6 & 52.4 & 5.22 & 61.4 & 63.7 & 33.5 & 0.13 & 0.10 \\
\hline & 100PS & 565.3 & 259.9 & 54.0 & 5.41 & 60.4 & 59.3 & 32.4 & 0.13 & 0.09 \\
\hline & $75 \mathrm{~V}$ & 654.1 & 311.9 & 52.3 & 5.58 & 65.1 & 61.6 & 33.0 & 0.14 & 0.11 \\
\hline & $100 \mathrm{~V}$ & 564.4 & 259.9 & 54.0 & 4.80 & 52.6 & 53.0 & 29.8 & 0.11 & 0.08 \\
\hline & 75PV & 686.4 & 332.1 & 51.6 & 4.72 & 57.8 & 63.9 & 32.3 & 0.13 & 0.09 \\
\hline & 100PV & 697.4 & 326.4 & 53.2 & 5.41 & 59.1 & 67.0 & 35.1 & 0.13 & 0.10 \\
\hline & 75PS+V & 600.3 & 270.8 & 54.9 & 5.20 & 59.3 & 54.9 & 30.2 & 0.11 & 0.08 \\
\hline & $100 P S+V$ & 535.5 & 231.4 & 56.8 & 4.91 & 47.4 & 50.2 & 25.9 & 0.14 & 0.12 \\
\hline & 75PS+PV & 670.3 & 315.9 & 52.9 & 5.16 & 56.8 & 59.1 & 31.8 & 0.13 & 0.09 \\
\hline & $100 P S+P V$ & 628.3 & 305.4 & 51.4 & 5.27 & 59.5 & 57.8 & 31.4 & 0.13 & 0.10 \\
\hline & $75 \mathrm{~V}+\mathrm{PV}$ & 637.0 & 290.5 & 54.4 & 5.37 & 60.0 & 60.9 & 30.6 & 0.14 & 0.09 \\
\hline & $100 V+P V$ & 589.3 & 271.3 & 54.0 & 4.72 & 49.3 & 53.1 & 25.8 & 0.12 & 0.08 \\
\hline & $\operatorname{LSD}(p=0.05)$ & 126.64 & 62.767 & 8.5273 & 0.6995 & 8.941 & 8.9158 & 4.3234 & 0.0505 & 0.0633 \\
\hline
\end{tabular}

BS = Berry set; PS = Pea size; V = Véraison; PV = Post-véraison; $75=75 \%$ field water capacity irrigation; $100=100 \%$ field water capacity irrigation; $\mathrm{NI}=\mathrm{No}$ irrigation; Trm. av. = Treatment average; $\mathrm{H} 1=\mathrm{Harvest} 1$; H2 = Harvest 2 ; H3 = Harvest 3; Antho pot pH 1 = Total available anthocyanin; Antho pot pH $3.2=$ Anthocyanin in average wine medium; AE $(\%)=$ Anthocyanin extractability; MP $(\%)=$ Seed tannin contribution; I $280=$ Phenol index; DMAC = Total tannin monomers

TABLE 4

Effect of level and stage of irrigation on wine total anthocyanin and phenolic content of Shiraz/Richter 99.

\begin{tabular}{|c|c|c|c|c|}
\hline \multirow[b]{2}{*}{ Stage } & \multirow{2}{*}{$\begin{array}{c}\text { Irrigation Treatment } \\
\text { (stage+level) }\end{array}$} & \multicolumn{2}{|c|}{ Anthocyanins } & \multirow{2}{*}{$\begin{array}{c}\text { Phenolic } \\
\mathbf{A}_{280}\end{array}$} \\
\hline & & $\mathbf{A}_{520}$ & $\mathbf{A}_{420}$ & \\
\hline \multirow[t]{15}{*}{ H1 } & NI & 0.70 & 0.50 & 7.15 \\
\hline & 75All stages & 0.45 & 0.30 & 5.45 \\
\hline & 100All stages & 0.50 & 0.40 & 5.90 \\
\hline & 75PS & 0.75 & 0.55 & 7.75 \\
\hline & 100PS & 0.55 & 0.40 & 6.20 \\
\hline & $75 \mathrm{~V}$ & 0.75 & 0.50 & 7.20 \\
\hline & $100 \mathrm{~V}$ & 0.65 & 0.45 & 6.95 \\
\hline & $75 \mathrm{PV}$ & 0.75 & 0.50 & 7.25 \\
\hline & 100PV & 0.75 & 0.50 & 7.60 \\
\hline & 75PS $+\mathrm{V}$ & 0.75 & 0.50 & 7.25 \\
\hline & $100 P S+V$ & 0.55 & 0.35 & 5.45 \\
\hline & 75PS+PV & 0.70 & 0.50 & 7.20 \\
\hline & $100 P S+P V$ & 0.65 & 0.45 & 6.65 \\
\hline & $75 \mathrm{~V}+\mathrm{PV}$ & 0.75 & 0.50 & 7.35 \\
\hline & $100 V+P V$ & 0.55 & 0.35 & 6.00 \\
\hline
\end{tabular}


TABLE 4 (CONTINUED)

\begin{tabular}{|c|c|c|c|c|}
\hline \multirow[t]{2}{*}{$\overline{\text { Stage }}$} & \multirow{2}{*}{$\begin{array}{c}\text { Irrigation Treatment } \\
\text { (stage+level) }\end{array}$} & \multicolumn{2}{|c|}{ Anthocyanins } & \multirow{2}{*}{$\begin{array}{c}\text { Phenolic: } \\
\mathbf{A}_{280}\end{array}$} \\
\hline & & $\mathbf{A}_{520}$ & $\mathbf{A}_{420}$ & \\
\hline \multirow[t]{15}{*}{ H2 } & NI & 0.85 & 0.65 & 8.60 \\
\hline & 75All stages & 0.65 & 0.45 & 7.75 \\
\hline & 100All stages & 0.75 & 0.55 & 8.20 \\
\hline & 75PS & 1.05 & 0.75 & 9.90 \\
\hline & 100PS & 0.85 & 0.65 & 8.55 \\
\hline & $75 \mathrm{~V}$ & 0.95 & 0.70 & 9.55 \\
\hline & $100 \mathrm{~V}$ & 0.85 & 0.60 & 8.90 \\
\hline & 75PV & 1.05 & 0.75 & 9.70 \\
\hline & $100 \mathrm{PV}$ & 1.00 & 0.75 & 9.65 \\
\hline & 75PS $+\mathrm{V}$ & 0.95 & 0.70 & 9.55 \\
\hline & $100 \mathrm{PS}+\mathrm{V}$ & 0.60 & 0.45 & 7.50 \\
\hline & 75PS+PV & 0.90 & 0.65 & 9.10 \\
\hline & $100 P S+P V$ & 0.75 & 0.55 & 8.15 \\
\hline & $75 \mathrm{~V}+\mathrm{PV}$ & 0.90 & 0.70 & 9.40 \\
\hline & $100 \mathrm{~V}+\mathrm{PV}$ & 0.65 & 0.50 & 7.80 \\
\hline \multirow[t]{16}{*}{ H3 } & NI & 1.10 & 0.85 & 10.15 \\
\hline & 75All stages & 0.85 & 0.70 & 9.40 \\
\hline & 100All stages & 0.85 & 0.70 & 9.50 \\
\hline & 75PS & 1.45 & 1.10 & 11.45 \\
\hline & 100PS & 1.20 & 0.90 & 10.40 \\
\hline & $75 \mathrm{~V}$ & 1.10 & 0.85 & 10.20 \\
\hline & $100 \mathrm{~V}$ & 1.05 & 0.80 & 10.25 \\
\hline & 75PV & 1.30 & 0.95 & 10.40 \\
\hline & $100 \mathrm{PV}$ & 1.20 & 0.90 & 10.55 \\
\hline & 75PS $+\mathrm{V}$ & 1.20 & 0.95 & 10.80 \\
\hline & $100 \mathrm{PS}+\mathrm{V}$ & 0.95 & 0.70 & 9.50 \\
\hline & 75PS+PV & 1.35 & 1.05 & 11.15 \\
\hline & $100 \mathrm{PS}+\mathrm{PV}$ & 1.15 & 0.90 & 10.25 \\
\hline & $75 V+P V$ & 1.10 & 0.85 & 10.30 \\
\hline & $100 \mathrm{~V}+\mathrm{PV}$ & 0.95 & 0.70 & 9.60 \\
\hline & $\operatorname{LSD}(p=0.05)$ & 0.243 & 0.182 & 1.279 \\
\hline
\end{tabular}

$\mathrm{BS}=$ Berry set; $\mathrm{PS}=$ Pea size; $\mathrm{V}=$ Véraison; PV = Post-véraison; $75=75 \%$ field water capacity irrigation; $100=100 \%$ field water capacity irrigation; $\mathrm{NI}=$ No irrigation; $\mathrm{H} 1=$ Harvest $1 ; \mathrm{H} 2=$ Harvest $2 ; \mathrm{H} 3=$ Harvest 3

for the skin and whole berry composition, the $75 \%$ PS, PV irrigation and $75 \% \mathrm{PS}+\mathrm{PV}$ irrigation resulted in a good expression of wine colour at all stages. The $75 \% \mathrm{~V}$ and $75 \%$ $\mathrm{PS}+\mathrm{V}$ irrigation also seemed reasonably successful in this regard.

The organoleptic wine quality and wine style data (Table 5) correspond to the grape and wine composition data (Tables 2, 3 and 4). The total flavour intensity of the wine was highest at harvests two and three and seemed higher with less irrigation water. The spiciness increased up to the second harvest and then decreased. Berry fruit occurrence was highest at harvests two and three. Acidity seemed reasonably well maintained at all harvest stages. The body of the wine was clearly improved by lower irrigation volumes at the first two harvests; at harvest three the effects were less evident. The wine colour was also better perceived when the irrigation volume was reduced; this effect again faded to a large extent at the last harvest stage. The perceived astringency decreased from the first to the last harvest stage. These trends are confirmed by the PCA analyses at the different harvest stages (Figs 4, 5 and 6), with the total contribution of PC (F) 1 and 2 decreasing strongly from the first two stages $(79.5 \%$ and $76.2 \%)$ to the last harvest stage (47.7\%), meaning that factors other than the treatments per se had a higher impact on the sensorial perception of the wines or, vice versa, that seasonal treatment effects on wine quality were largely negligible when harvesting took place at such a late stage. This again confirms that overripe grapes 
may to a large extent nullify any special seasonal treatments that focused on obtaining a specific wine style per terroir.

Non-irrigated wines failed to result in exceptional wine quality at any harvest stage. However, in comparison to the irrigation treatments applied at all stages, a better result on overall quality was obtained with no irrigation. At each harvest stage, different styles of wines were featured by the different treatments. At the first harvest stage, the $75 \% \mathrm{PV}$, $100 \% \mathrm{PV}, 75 \% \mathrm{PS}+\mathrm{V}$ and $75 \% \mathrm{PS}+\mathrm{PV}$ irrigations gave the most prominent wines, with the first-mentioned representing a wine style marked by fruitiness, colour, good flavour, reasonably prominent acidity and good body, and the latter three treatments a wine style with reasonably prominent vegetative, spicy and astringency notes. At the second harvest stage, the vines irrigated $75 \%$ at PS, $75 \%$ at PS+PV and $75 \%$ at $\mathrm{PV}$ gave the most prominent wines, with the former two treatments representing a prominently spicy wine style and the latter a highly complex wine style with good colour and (fruity) flavour and notable body. At the third harvest stage, the $75 \% \mathrm{PV}, 100 \% \mathrm{PV}, 75 \% \mathrm{PS}$ and $75 \% \mathrm{PS}+\mathrm{PV}$ resulted in the better wines, with the former two representing a spicy, astringent and vegetative wine style with low acidity, and the latter two displaying a flavourful wine style with good body and colour.

It is clear that the style of wine is intimately linked to the quantity of water, stage of application and development of the grapes on the vine. At the last, high-ripeness stage, differences between treatments diminished to a large extent. This implies that, if grapes are forced or allowed to ripen to over-ripeness, it may have a tempering and even negative effect on the expected outcomes of seasonal cultivation efforts to produce unique wines per terroir, thereby also not supporting economic viability/sustainability.

The groups of treatments that performed best seemed to

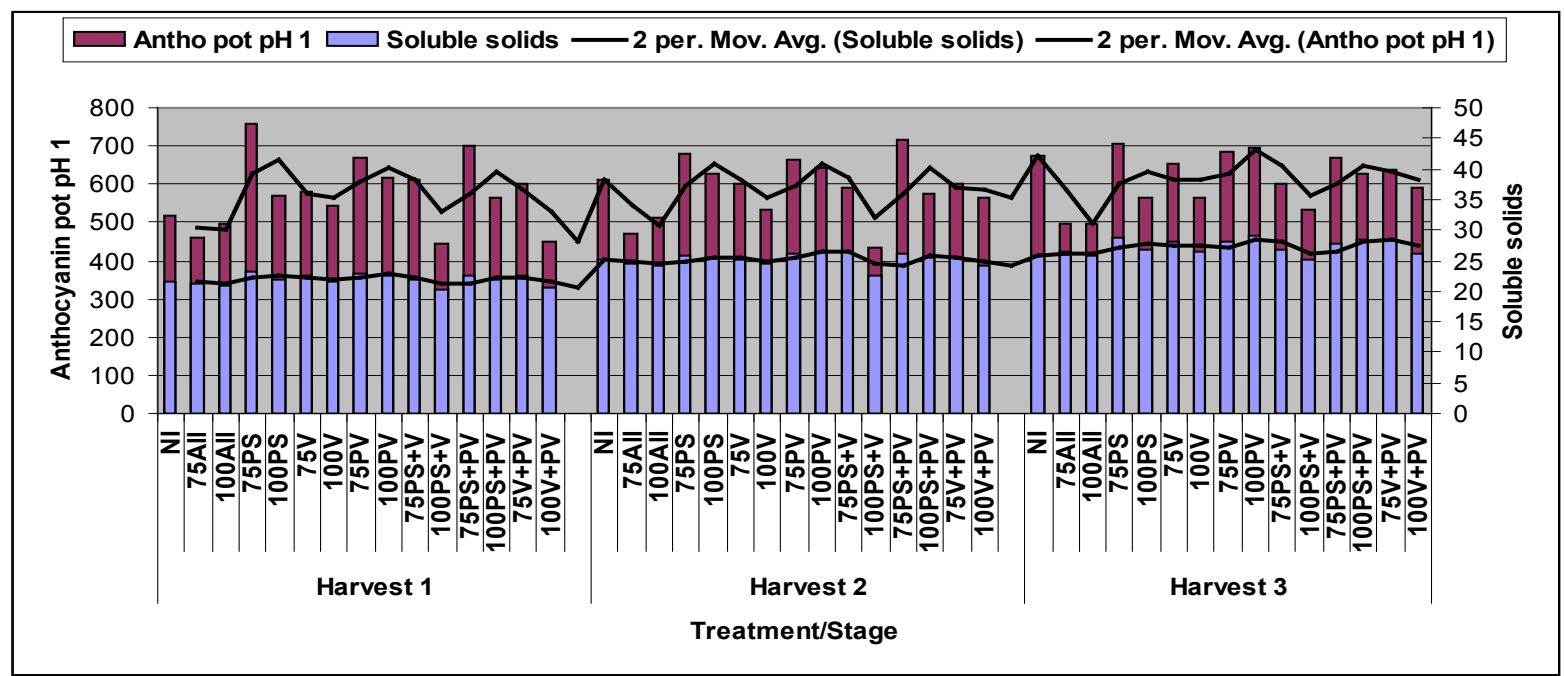

FIGURE 2

Effect of level and stage of irrigation on the relationship between whole berry anthocyanin (mg/l) extraction at $\mathrm{pH} 1.0$ and must soluble solids $\left({ }^{\circ} \mathrm{B}\right)$ of Shiraz/Richter 99.

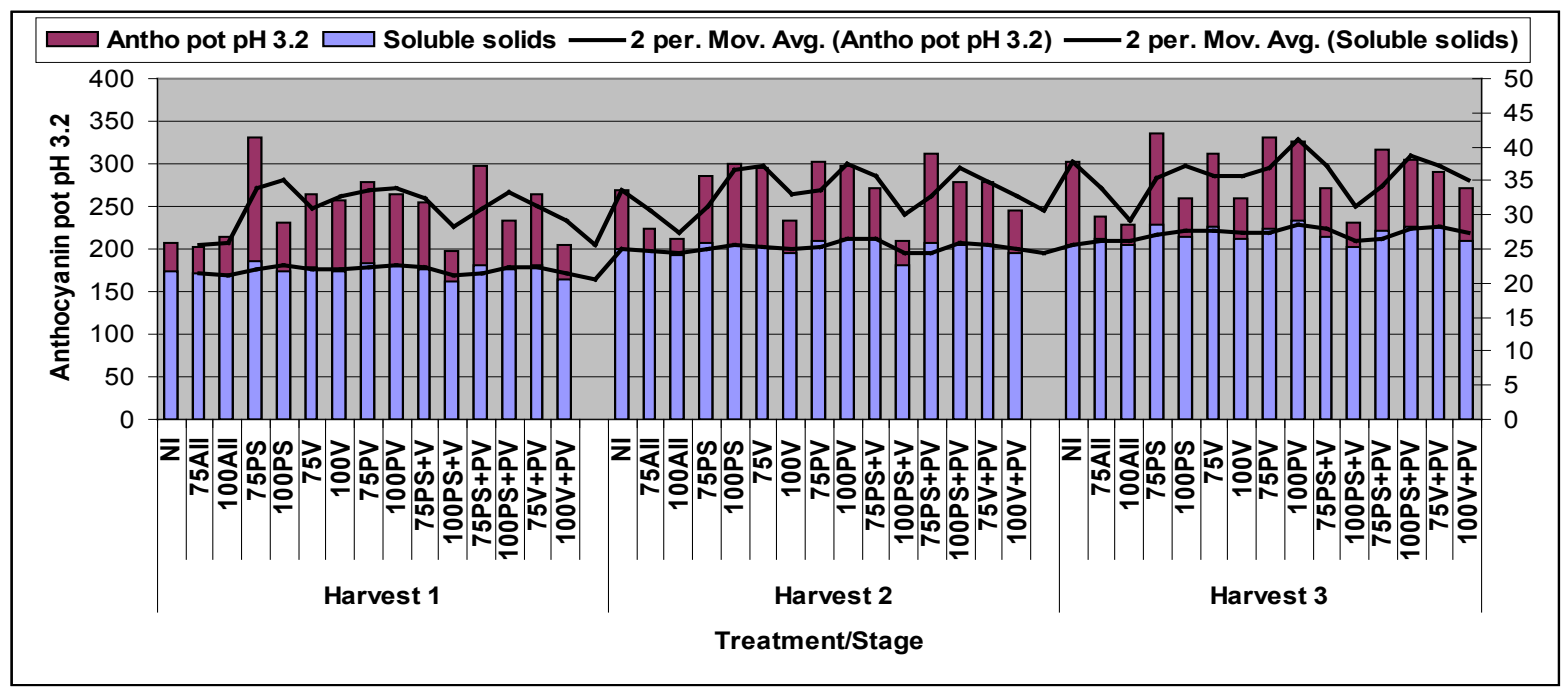

FIGURE 3

Effect of level and stage of irrigation on the relationship between whole berry anthocyanin (mg/l) extraction at $\mathrm{pH} 3.2$ and must soluble solids $\left({ }^{\circ} \mathrm{B}\right)$ of Shiraz/Richter 99. 


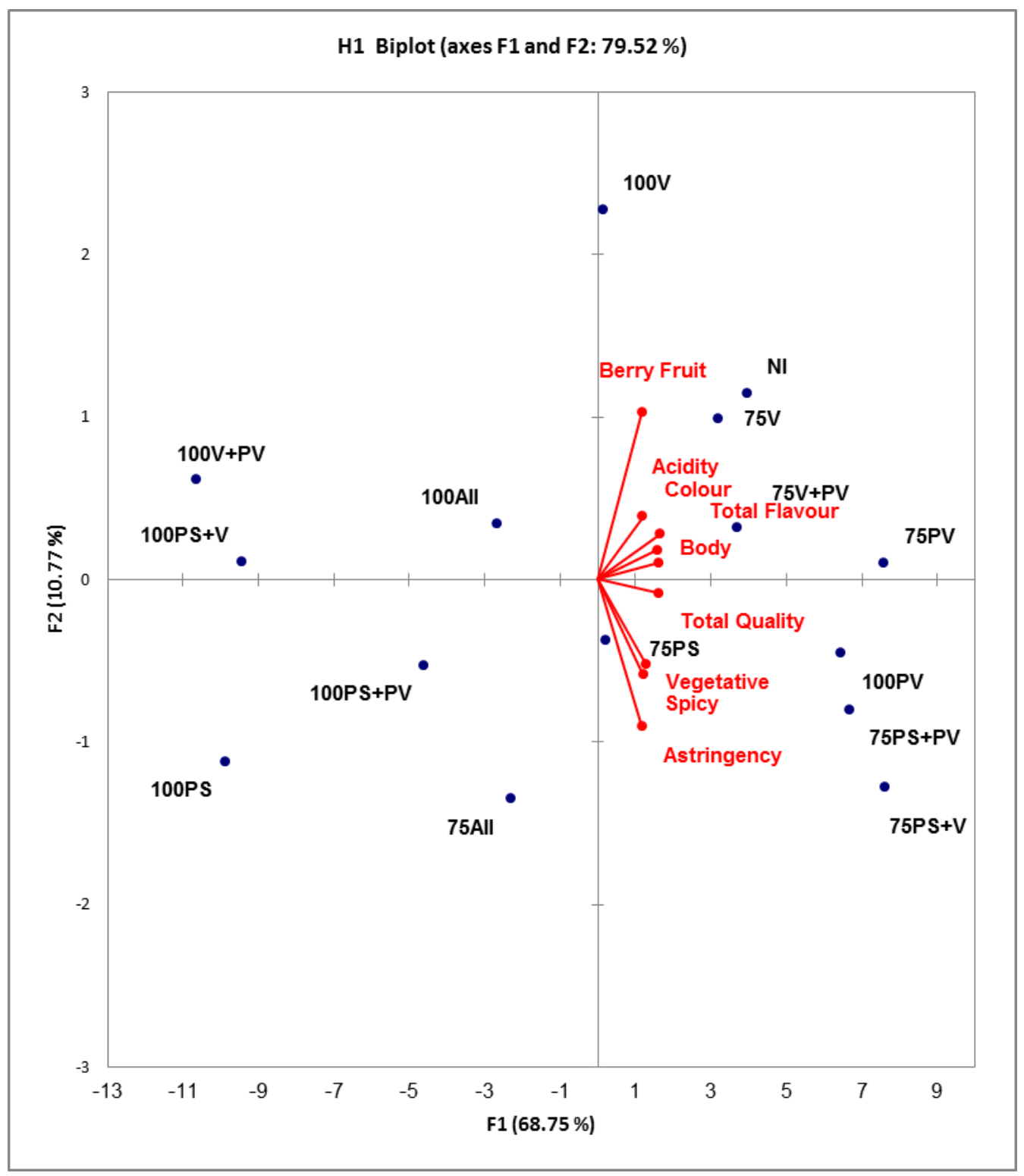

FIGURE 4

Principle component analysis biplot of sensorial variables and treatments at Harvest Stage 1 of Shiraz/Richter 99.

TABLE 5

Effect of level and stage of irrigation on organoleptic wine quality and wine style (expressed as \% values as marked by tasters on a non-structured $100 \mathrm{~mm}$ line scale) of Shiraz/Richter 99.

\begin{tabular}{llccccccccc}
\hline & $\begin{array}{l}\text { Irrigation } \\
\text { treatment } \\
\text { (stage+level) }\end{array}$ & $\begin{array}{c}\text { Total } \\
\text { flavour }\end{array}$ & Spicy & $\begin{array}{c}\text { Berry } \\
\text { fruit }\end{array}$ & $\begin{array}{c}\text { Vege- } \\
\text { tative }\end{array}$ & Acidity & Body & Colour & $\begin{array}{c}\text { Astrin- } \\
\text { gency }\end{array}$ & $\begin{array}{c}\text { Total } \\
\text { quality }\end{array}$ \\
\hline H1 & NI & 63.1 & 49.5 & 53.8 & 30.0 & 80.3 & 62.2 & 79.1 & 62.9 & 58.4 \\
& 75All stages & 55.3 & 44.2 & 37.1 & 40.0 & 73.1 & 50.0 & 57.5 & 64.2 & 55.6 \\
& 100All stages & 55.6 & 41.6 & 49.5 & 39.4 & 72.1 & 49.0 & 60.7 & 60.4 & 48.3 \\
& 75PS & 62.8 & 42.3 & 45.0 & 42.5 & 68.8 & 53.4 & 70.0 & 62.1 & 58.8 \\
& 100PS & 41.4 & 49.4 & 34.6 & 28.1 & 76.1 & 36.7 & 38.9 & 58.3 & 37.9 \\
& 75V & 61.3 & 49.2 & 51.3 & 47.5 & 81.9 & 53.6 & 79.4 & 54.2 & 55.3 \\
& 100V & 57.2 & 45.4 & 58.1 & 34.4 & 79.7 & 52.0 & 69.6 & 52.5 & 54.4 \\
& 75PV & 65.3 & 50.0 & 54.1 & 39.2 & 81.0 & 66.3 & 79.7 & 70.8 & 65.5 \\
& 100PV & 62.8 & 50.0 & 56.4 & 47.5 & 77.7 & 58.4 & 75.3 & 72.5 & 60.9 \\
& 75PS+V & 64.7 & 57.5 & 47.5 & 52.8 & 78.3 & 61.6 & 80.0 & 66.3 & 63.9 \\
& 100PS+V & 51.9 & 41.0 & 42.1 & 30.0 & 71.2 & 36.0 & 38.6 & 56.1 & 39.4 \\
\hline
\end{tabular}


TABLE 5 (CONTINUED)

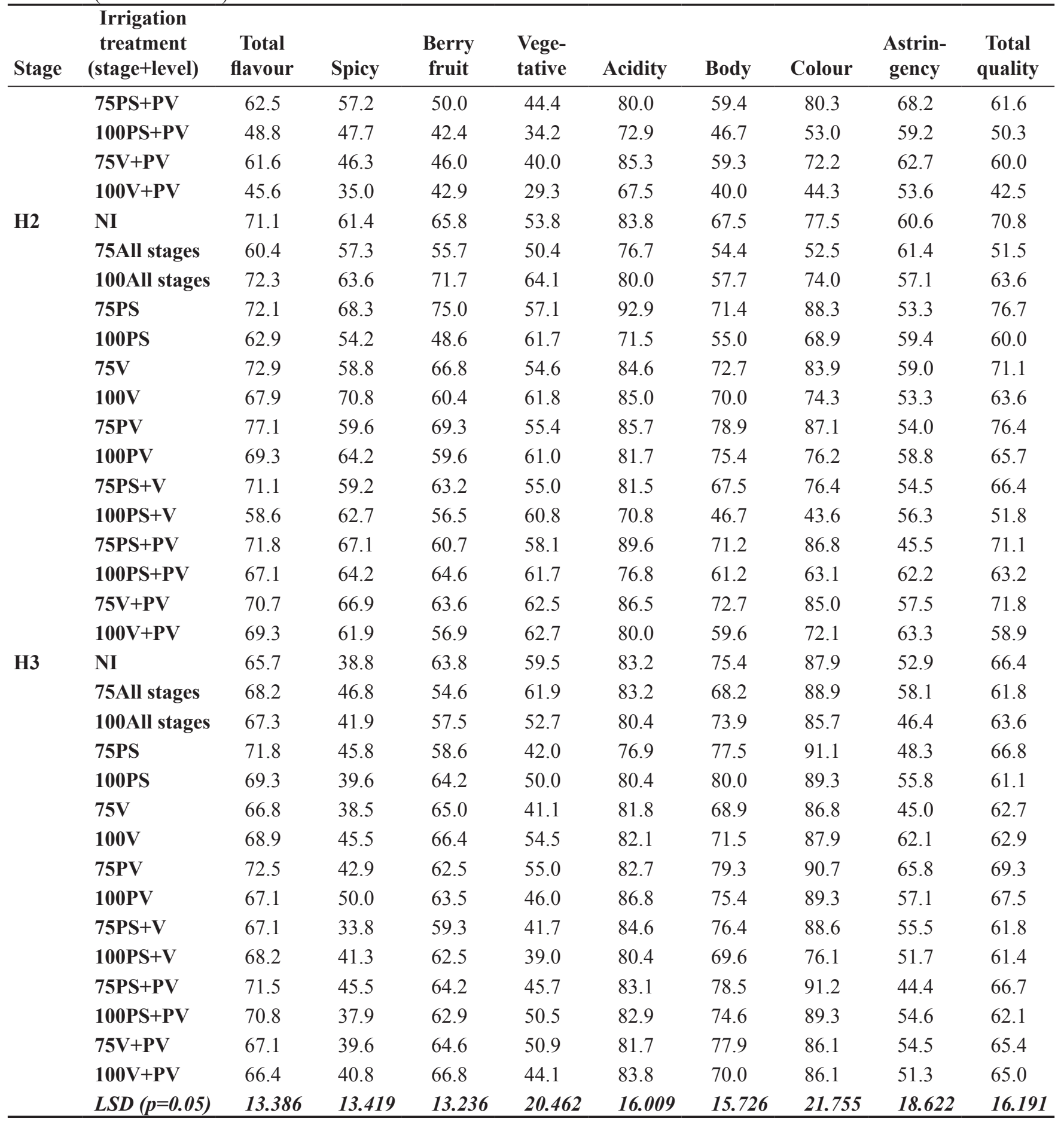

$\mathrm{BS}=$ Berry set; PS = Pea size; V = Véraison; PV = Post-véraison; $75=75 \%$ field water capacity irrigation; $100=100 \%$ field water capacity irrigation; $\mathrm{NI}=$ No irrigation; $\mathrm{H} 1=$ Harvest $1 ; \mathrm{H} 2=$ Harvest 2; H3 = Harvest 3

be those that included restricted PS irrigation $(75 \%$ in this study) and PV (three weeks after V) irrigation, but not in combination with any high-volume irrigation (to $100 \%$ field water capacity in this study). It is reasonable to assume that reaction trends would be similar under comparable terroir conditions and with genetic material and eco-physiological sensitivity analogous to that described in this study.

Although general behavioural and outcome trends are likely to remain largely unaffected, soil type and environmental conditions (including climatological patterns) would be major steering factors for vine water status, vegetative and reproductive growth characteristics and grape ripening dynamics, and therefore may have an impact on seasonal events and the composition of the wine style that eventually may be obtained with similar grapevine management under different terroir conditions.

\section{CONCLUSIONS}

Definitive guidelines regarding the effect of stage and volume of low-intensity (supplementary) irrigation under Mediterranean climate (high winter rainfall and occasional, infrequent summer rainfall) and medium-potential soil 


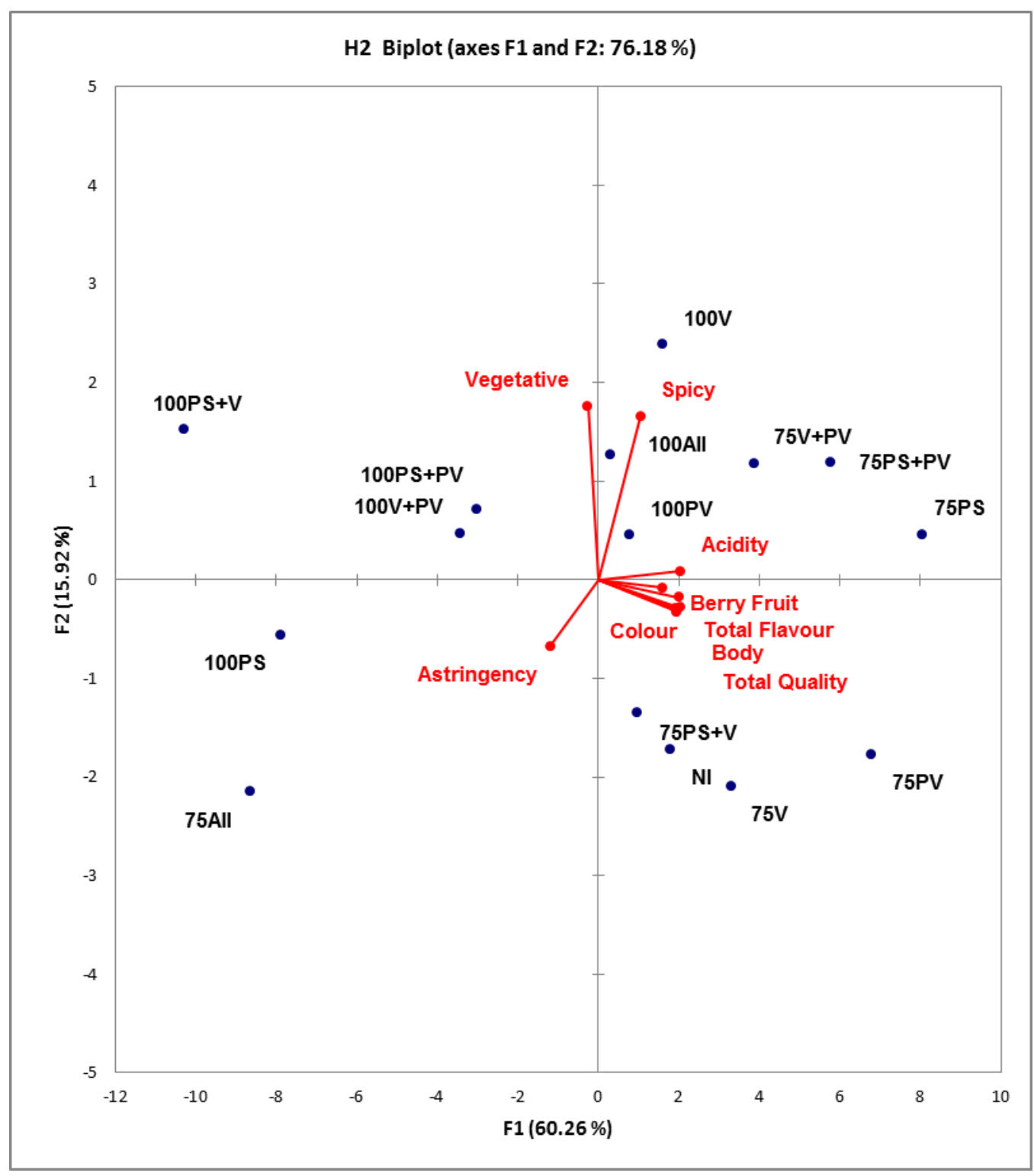

FIGURE 5

Principle component analysis biplot of sensorial variables and treatments at Harvest Stage 2 of Shiraz/Richter 99.

conditions on grape composition and wine quality and style were compiled. These certainly also have significance for other terroirs. It is clear that irrigation in terms of volume and stage, in combination with a definitive ripeness level, may also contribute largely to a required style of wine under the terroir conditions of the experiment. Restricted irrigation at pea berry size and at post-véraison (three weeks after véraison) (as a single-stage treatment or in combination) featured prominently as being favourable to grape and wine composition, as well as to wine sensorial quality, albeit resulting in different grape and wine styles. It seems reasonable to assume that Shiraz/Richter 99 vines and other cultivar-rootstock combinations with similar environment requirements or abiotic resistance, specifically drought resistance, and eco-physiological reaction would react similarly under analogous terroir conditions. An ultimate aim of research efforts could be to predict wine quality and style on the basis of soil and plant water relations, canopy appearance, berry physical structure and berry composition, at any given time during ripening.

The introduction of different ripeness levels added a further dimension to management effects, in this case with the focus on irrigation. Treatment effects were generally reduced at a late harvest stage. Over-ripe grapes seemed to minimise the opportunity for making a unique or even terroir-specific wine. It would also minimise the effect of any special cultivation practices followed during the season to a large extent, thereby not complementing management to achieve wine style preferences. Harvesting at optimal ripeness or within a window that allows the effects of terroir and vineyard-specific practices (including irrigation) to surface is critical.

The results contribute to the quest to obtain top quality, and different styles, of wine within a global environment that is challenged by the need for overall sustainability, along with the consideration of climate change as well as resource conservation. 


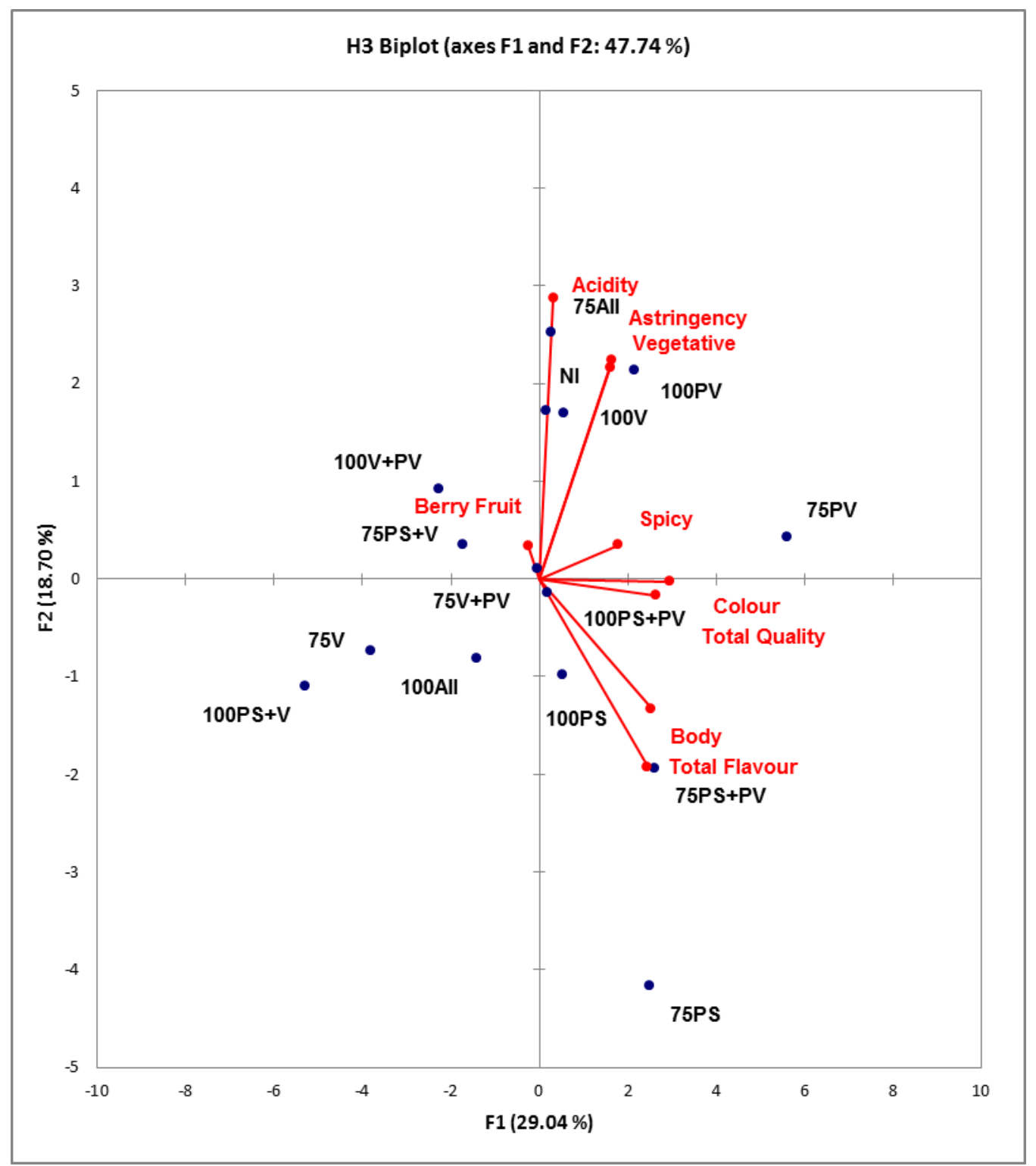

FIGURE 6

Principle component analysis biplot of sensorial variables and treatments at Harvest Stage 3 of Shiraz/Richter 99.

\section{LITERATURE CITED}

Anonymous, 2012. XLStat. Addinsoft, Paris.

Bautista-Ortín, A.B., Fernández-Fernández, J.I., López-Roca, J.M. \& Gómez-Plaza, E., 2006. The effect of grape ripening stage on red wine color. J. Int. Sci. Vigne Vin 40, 15-24.

Borsani, O., González-Neves, G., Ferrer, M. \& Monza, J., 2010. Anthocyanins accumulation and genes-related expression in berries of cv. Tannat (Vitis vinifera L.). J. Appl. Hortic. 12, 3-9.

Carbonneau, A., Deloire, A. \& Jaillard, B., 2007. La vigne: Physiologie, terroir, culture. Dunod, Paris.

Cheynier, V., Dueñas-Paton, M., Salas, E., Maury, C., Souquet, J.-M., Sarni-Manchado, P. \& Fulcrand, H., 2006. Structure and properties of wine pigments and tannins. Am. J. Enol. Vitic. 57, 298-305.

Cliff, M.A., Brau, N., King, M.C. \& Mazza, G., 2002. Development of predictive models for astringency from anthocyanin, phenolic and color analyses of British Columbia red wines. J. Int. Sci. Vigne Vin 36, 21-30.
De, D.N., 2000. Plant cell vacuoles. An introduction. CSIR, Collingwood, Australia.

De Beer, D., Joubert, E., Gelderblom, W.C.A. \& Manley, M., 2002. Phenolic compounds: A review of their possible role as in vivo antioxidants of wine. S. Afr. J. Enol. Vitic. 23, 48-61.

De Freitas, V.A.P., Glories, Y. \& Monique, A., 2000. Developmental changes of procyanidins in grapes of red Vitis vinifera varieties and their composition in respective wines. Am. J. Enol. Vitic. 51, 397-403.

Deloire, A., Zebic, O., Bernard, N., Brenon, E. \& Hunter, J.J., 2005. Influence de l'etat hydrique de la vigne sur le style de vin. Revue Fr. d'Oenologie 215, $11-15$.

De Souza, C.R., Maroco, J.P., Dos Santos, T.P., Rodrigues, M.L., Lopes, C.M., Pereira, J.S. \& Chaves, M.M., 2005. Grape berry metabolism in fieldgrown grapevines exposed to different irrigation strategies. Vitis 44, 103 109 .

Dreier, L.P., Hunter, J.J. \& Ruffner, H.P., 1998. Invertase activity, grape berry development and cell compartmentation. Plant Physiol. Biochem. 36, 865872 . 
Esteban, M.A., Villanueva, M.J. \& Lissarrague, J.R., 2001. Effect of irrigation on changes in the anthocyanin composition of the skin of cv. Tempranillo (Vitis vinifera) grape berries during ripening. J. Sci. Food Agric. 81, 409 - 420.

Esteban, M.A., Villanueva, M.J. \& Lissarrague, J.R., 2002. Relationships between different berry components in Tempranillo (Vitis vinifera L.) grapes from irrigated and non-irrigated vines during ripening. J. Sci. Food Agric. 82, 1136-1146.

Fournand, D., Vicens A., Sidhoum L., Souquet J-M., Moutounet M. \& Cheynier V., 2006. Accumulation and extractability of grape skin tannins and anthocyanins at different advanced physiological stages. J. Agric. Food Chem. 54, 7331-7338.

Gawel, R., 1998. Red wine astringency: A review. Aust. J. Grape Wine Res.4, 74-95.

González-Neves, G., Gil, G. \& Ferrer, M., 2002. Effect of different vineyard treatments on the phenolic contents in Tannat (Vitis vinifera L.) grapes and their respective wines. Food Sci. Tech. Int. 8, 315-317.

Guidoni, S. \& Argamante, N., 2003. Influenza del diradamento dei grappoli sull'accumulo di antociani nelle uve. Quad. Vitic. Enol. Univ. Torino 26, $27-42$

Guidoni, S. \& Hunter, J.J., 2012. Anthocyanin profile in berry skins and fermenting must/wine, as affected by grape ripeness level of Vitis vinifera cv. Shiraz/R99. Eur. Food Res. Technol. 235, 397-408. doi:10.1007/s00217012-1744-5.

Hanlin, R.L. \& Downey, M.O., 2009. Condensed tannin accumulation and composition in skin of Shiraz and Cabernet Sauvignon grapes during berry development. Am. J. Enol. Vitic. 60, 13-23.

Hilbert, G., Soyer, J.P., Molot, C., Giraudon, J., Milin, S. \& Gaudillère, J.P., 2003. Effects of nitrogen supply on must quality and anthocyanin accumulation in berries of cv. Merlot. Vitis 42, 69-76.

Hunter, J.J., 2000. Implications of seasonal canopy management and growth compensation in grapevine. S. Afr. J. Enol. Vitic. 21, 81-91.

Hunter, J.J. \& Bonnardot, V., 2011. Suitability of some climatic parameters for grapevine cultivation in South Africa, with focus on key physiological processes. S. Afr. J. Enol. Vitic. 32, 137-154.

Hunter, J.J. \& Deloire, A., 2005. Relationship between sugar loading and berry size of ripening Syrah/R99 grapes as affected by grapevine water status. Proc. $14^{\text {th }}$ GESCO Symposium, August 2005, Geisenheim, Germany. pp. $127-133$.

Hunter, J.J. \& Deloire, A., 2006. Terroir and vine water relation effects on grape ripening and wine quality of Syrah/R99. Proc. VI ${ }^{\text {th }}$ Int. Terroir Congress, July 2006, Bordeaux and Montpellier, France. pp. 110 - 116.

Hunter, J.J. \& Ruffner, H.P., 2001. Assimilate transport in grapevines effect of phloem disruption. Aust. J. Grape Wine Res. 7, 118-126.

Hunter, J.J., Archer, E. \& Volschenk, C.G., 2010. Vineyard management for environment valorisation. In: VIII ${ }^{\text {th }}$ Int. Terroir Congress, June 2010, Soave, Italy. pp. 7-3-7-15.

Hunter, J.J., Archer, E., Strever, A. \& Volschenk, C.G., 2011. Integrative strategies for sustainable viticulture and terroir valorisation. Proc. 17 $7^{\text {th }}$ GiESCO Symp., Aug/Sept. 2011, Asti-Alba, Italy. pp. 73 - 78.

Hunter, J.J., De Villiers, O.T. \& Watts, J.E., 1991. The effect of partial defoliation on quality characteristics of Vitis vinifera L. cv. Cabernet Sauvignon grapes. II. Skin colour, skin sugar, and wine quality. Am. J. Enol. Vitic. $42,13-18$

Hunter, J.J., Pisciotta, A., Voschenk, C.G., Archer, E., Novello, V., Deloire, A. \& Nadal, M., 2004. Role of harvesting time/optimal ripeness in zone/ terroir expression. In: Proc. Joint Conference (SASEV, OIV, GESCO) on Viticultural Zoning, November 2004, Cape Town, South Africa. pp. 466 478 .
Hunter, J.J., Volschenk, C.G., Novello, V., Strever, A.E. \& Fouché, G.W., 2014. Integrative effects of vine water relations and grape ripeness level of Vitis vinifera L. cv. Shiraz/Richter 99. I. Physiological changes and vegetative-reproductive growth balances. S. Afr. J. Enol. Vitic. 35, 332-358.

Iland, P., Dry, P., Proffitt, T. \& Tyerman, S., 2011. The grapevine: From the science to the practice of growing vines for wines. Patrick Iland Wine Promotions Pty, Adelaide, Australia.

Jackson, R.S., 2002. Wine tasting: A professional handbook. Elsevier Academic Press.

Keller, M. \& Hrazdina, G., 1998. Interaction of nitrogen availability during bloom and light intensity during véraison: II. Effects on anthocyanin and phenolic development during ripening. Am. J. Enol. Vitic. 49, 341-349.

Little, T.M. \& Hills, F.J., 1978. Agricultural experimentation: Design and Analysis. Wiley, New York, 125-137.

McCarthy, M.G., 1999. Weight loss from ripening berries of Shiraz grapevines (Vitis vinifera L. cv. Shiraz). Aust. J. Grape Wine Res. 5, 10-16.

Myburgh, P.A., 2005. Water status, vegetative growth and yield responses of Vitis vinifera L. cvs. Sauvignon blanc and Chenin blanc to timing of irrigation during berry ripening in the coastal region of South Africa. S. Afr. J. Enol. Vitic. 26, 59-67.

Myburgh, P.A., 2006. Juice and wine quality responses of Vitis vinifera L. cvs. Sauvignon blanc and Chenin blanc to timing of irrigation during berry ripening in the coastal region of South Africa. S. Afr. J. Enol. Vitic. 27, 1-7.

Nadal, M. \& Hunter, J.J., 2007. Different wine styles as related to ripeness level of Syrah/R 99 grapes. Proc. Int. Intervitis Interfructa Congress, Stuttgart, Germany. pp. $139-148$

Nunan, K.J., Sims, I.M., Bacic, A., Robinson, S.P. \& Fincher, G.B., 1998 Changes in cell wall composition during ripening of grape berries. Plant Physiol. 118, 783-792

Ojeda, H., Andary, C., Kraeva, E., Carbonneau, A. \& Deloire, A., 2002. Influence of pre- and postveraison water deficit on synthesis and concentration of skin phenolic compounds during berry growth of Vitis vinifera cv. Shiraz. Am. J. Enol. Vitic. 53, 261-267.

Ott, R.L., 1998. An introduction to statistical methods and data analysis. Duxbury Press, Belmont, California.

Ribéreau-Gayon, P., Glories, Y., Maujean, A. \& Dubourdieu, D., 2000. Handbook of enology, vol. 2. John Wiley \& Sons Ltd, USA. pp. $129-185$.

Roby, G. \& Matthews, M.A., 2004. Relative proportions of seed, skin and flesh, in ripe berries from Cabernet Sauvignon grapevines grown in a vineyard either well irrigated or under water deficit. Aust. J. Grape Wine Res. $10,74-82$

Romero-Cascales, I., Ortega-Regules, A., López-Roca, J.M., FernándezFernández, J.I. \& Gómez-Plaza, E., 2005. Differences in anthocyanin extractability from grapes to wines according to variety. Am. J. Enol. Vitic. $56,212-219$

Ruffner, H.P., Adler, S. \& Rast, D. M., 1990. Soluble and wall associated forms of invertase in Vitis vinifera. Phytochem. 29, 2083-2086.

SAS, 2012. SAS Version 9.2., SAS Institute Inc, Cary, North Carolina 27513.

Shapiro, S.S. \& Wilk, M.B., 1965. An analysis of variance test for normality (complete samples). Biometrika 52, 591-611.

Sipiora M.J. \& Granda, M.J.G., 1998. Effects of pre-véraison irrigation cutoff and skin contact time on the composition, color, and phenolic content of young Cabernet Sauvignon wines in Spain. Am. J. Enol. Vitic. 49, 152162 
Squadrito, M., Corona, O., Ansaldi, G. \& Di Stefano, R., 2010. Evolution of anthocyanin profile from grape to wine. J. Int. Sci. Vigne Vin 44, 167-177.

Vivas, N., Glories, Y., Lagune, L., Saucier, C. \& Agustin, M., 1994. Estimation of the polymerisation level of procyanidins from grapes and wines by use of p-dimethylaminocinnamaldehyde. J. Int. Sci. Vigne Vin 28, 319-336.
Williams, L.E. \& Matthews, M.A., 1990. Grapevine. In: Stewart, B.A. \& Nielsen, D.R. (eds). Irrigation of agricultural crops. Agronomy monograph (No. 30). ASA-CSSA-SSSA, Madison. pp. 1019 - 1055.

Zhang, X.Y., Wang, X.L., Wang, X.F., Xia, G.H., Pan, Q.H., Fan, R.C., Wu, F.Q., Wu, X.C. \& Zhang, D.P., 2006. A shift of phloem unloading from symplasmic to apoplasmic pathway is involved in developmental onset of ripening in grape berry. Plant Physiol. 142, 220-232. 